DOI: https://doi.org/10.32839/2304-5809/2020-12-88-22

УДК 336.14:352(477)

Брежнева-Срмоленко О.В., Тіткова Н.П., Черкасова Т.М. Дніпровський державний технічний університет

\title{
ТЕОРЕТИЧНІ І ПРАКТИЧНІ АСПЕКТИ ФУНКЦІОНУВАННЯ ЄДИНОГО КАЗНАЧЕЙСЬКОГО РАХУНКУ ЯК ОСНОВНОГО РАХУНКУ ДЕРЖАВИ
}

Анотація. У статті розкрито економічну сутність та роль єдиного казначейського рахунку (СКР) як основного елемента функціонування казначейської системи виконання державного та місцевих бюджетів. Визначено, що фрункціннвання СКР забезпечуе казначейське обслуговування бюджетних коштів; зарахування податків і зборів (обов'язкових платежів) та інших надходжень, передбачених законодавством, до державного та місцевих бюджетів. Розглянуто показники надходжень на казначейські рахунки в динаміці. Проаналізовано залишки та виявлено негативні тенденції динаміки змін показників Державної казначейської служби України. Здійснено моделювання залежності обсягу залишків на ЄКР від основних чинників впливу на їх обсяги. Поліноміальна лінія тренду залишків ЄКР свідчить про існування трьох незалежних періодів дослідження залишків коштів на СКР.

Ключові слова: единий казначейський рахунок, залишки, доходи бюджету, видатки бюджету, державний борг, гарантований борг.

\section{Brezhnieva-Yermolenko Olha, Titkova Natalia, Cherkasova Tetyana Dnipro State Technical University}

\section{THEORETICAL AND PRACTICAL ASPECTS OF THE FUNCTIONING OF THE SINGLE TREASURY ACCOUNT AS THE MAIN ACCOUNT OF THE STATE}

Summary. The article reveals the economic essence and role of The Unified Treasury Account (UTA) as the main element of functioning of the treasury system of a state and local budgets. The following methods were used in the study: system method, logical method, mathematical method, method of analysis etc. It is determined that functioning of UTA provides treasury service of budget funds, crediting of taxes and fees (mandatory payments) and other revenues provided by the law to the state and local budgets. UTA provides an opportunity to quickly mobilize funds received during a day to accounts opened with the State Treasury of Ukraine, and use them for budget expenditures, and other operations that do not contradict the law. UTA provides optimal opportunities for the legislature and executive to take operational decisions to ensure the implementation of budgets, and effective public debt management, helps to obtain real-time information on the amount of funds on UTA and speeds up the settlement of funds accounted for UTA. The operation of UTA ensures the placement on a competitive basis and/or through auctions of temporarily free UTA funds on deposits or through the purchase of government securities with the subsequent return of such funds by the end of the current budget period, and provides opportunities. Raising funds of UTA on a revolving basis is used to cover temporary cash gaps in local budgets, the Pension Fund of Ukraine and provide medium-term loans to local budgets. The authors investigated the indicators of revenues to treasury accounts in the dynamics. The balances and negative tendencies of the dynamics of changes in the indicators of the State Treasury Service of Ukraine were analyzed. The dependence of the volume of balances on UTA on the main factors influencing their volumes is modeled. The polynomial line of UTA balance trend indicates the existence of three independent periods of UTA balance. Keywords: The Unified Treasury Account, balances, budget revenues, budget expenditures, public debt, guaranteed debt.

$\Pi$ остановка проблеми. На сьогоднішній день постає питання щодо підвищення дієвості й ефрективності функціонування казначейської системи виконання державного та місцевих бюджетів, спрямованої на зміцнення державної фінансової системи, дотримання принципів повноти, ефективності та результативності, цільового використання бюджетних коштів, покращення якості послуг, що надаються органами Державної казначейської служби України. Концентрація на единому казначейському рахунку дозволяе не лише акумулювати фінансові ресурси, не лише контролювати їх цільове використання, не лише прогнозувати майбутні залишки або нестачу бюджетних коштів, а показуе його роль та економічну сутність. Одним з ключових моментів організації казначейського обслуговування фінансових ресурсів є метод единого казначейського рахунку в системі казначейства.
Аналіз останніх досліджень і публікацій. Дослідженню питань, пов'язаних з управління доходами і видатками бюджету присвячено роботи багатьох вітчизняних науковців, серед яких: О.Д. Василик, В.М. Опарін, С.I. Юрій та ін. Становлення і розвиток казначейського виконання бюджету розглянули такі вчені як Й.Н. Бескид, П.Г. Петрашко, С.Е. Прокофьев, С.I. Юрій, О.О. Чечуліна.

Виділення невирішених раніше частин загальної проблеми. Відсутність ефективних механізмів управління фінансовими потоками, в т.ч. тимчасово вільними коштами, засвідчуе необхідність запровадження комплексних заходів для вирішення проблем, пов'язаних 3 недостатньо ефрективним управлінням наявними коштами Державного бюджету України та недосконалістю існуючої системи управління видатками.

Мета статті. Головною метою ціеї роботи $є$ дослідження теоретичних і практичних аспектів 
функціонування единого казначейського рахунку як основного рахунку держави для проведення фінансових операщій та ефективного управління коштами державного та місцевих бюджетів.

Виклад основного матеріалу. Функціонування единого казначейського рахунку як основного рахунку держави для проведення фінансових операцій та ефективного управління коштами державного та місцевих бюджетів через СЕП НБУ регламентуеться Положенням про единий казначейський рахунок, затверджене наказом Державної казначейської служби України від 26 червня 2002 року за № 122 .

Єдиний казначейський рахунок - це рахунок, відкритий Державній казначейській службі України в Національному банку України для обліку коштів та здійснення розрахунків у Системі електронних платежів Нащіонального банку України. Сдиний казначейський рахунок є основним рахунком держави для проведення фінансових операцій та ефрективного управління коштами державного та місцевих бюджетів.

Як зазначають автори монографіï «Система казначейства: управління фінансовими ресурсами»: «...в сучасних умовах органи Державного казначейства постають одним із найактивніших учасників в процесі управлінні регіональними фінансовими ресурсами через реалізацію законодавчо прийнятих механізмів та процедур виконання місцевих бюджетів відповідно до вимог бюджетного законодавства. Вітчизняна практика та світовий досвід доводять, що найефективнішим $є$ управління фінансовими ресурсами 3 використанням касового виконання бюджетів в системі казначейства» [1, с. 94].

Єдиний казначейський рахунок об'еднуе систему рахунків, що діють в единому режимі та через які в системі казначейства проводяться операції за доходами та видатками бюджетів усіх рівнів відповідно до Закону України про Державний бюджет України на відповідний рік. Це дає можливість в системі казначейства в режимі реального часу отримувати інформацію про рух та наявність коштів на единий казначейський рахунок як результат здійснення операцій на всіх його бюджетних та не бюджетних рахунках.

Позиції дослідників сходяться у тому, що «реалізація фонкції управління бюджетними потоками держави стала можливою через консолідацію фінансових ресурсів держави на единому казначейському рахунку. Запровадження ЄКР, на який зараховуються державні доходи і з якого здійснюються видатки, дозволяе органам казначейства мати вичерпну інформацію про стан державних фінансів, а отже, володіти фінансовим важелями макроекономічного регулювання» [2, с. 126].

Концентрація на единому казначейському рахунку дозволяе не лише акумулювати фінансові ресурси, не лише контролювати ї цільове використання, не лише прогнозувати майбутні залишки або нестачу бюджетних коштів, а показуе його роль та економічну сутність.

Аналіз стану залишків коштів на ЄКР поданих у табл. 1 засвідчуе негативні тенденції динаміки змін показників на СКР ДКСУ. Залишки коштів на единому казначейському рахунку на 1 січня 2019 року становили 9861 млн грн, що майже в два рази більше, ніж на 1 грудня 2018 року. Мінімальний залишок коштів на ЄКР становив $458,1 \mathrm{млн} \mathrm{грн} \mathrm{на} \mathrm{01.01.2013} \mathrm{року,} \mathrm{а} \mathrm{максималь-}$ ний - 14257, 8 млн грн - на 01.01.2016 р. Найбільший приріст залишків ЄКР спостерігався у 2013 рощі і він склав - 280\%, а від'ємний приріст зафріксовано у 2009 та 2012 роках - 86,3\% та 77,8\% відповідно. На превеликий жаль, рівень залишків у 2019 р. майже не відрізняється (на 2146,3 млн. грн. більше) від залишків СКР 2009 року. На 01.01.2020 р. обсяг залишків ЄКР досяг свого історичного максимуму $-17547,5$ млн. грн.

Разом 3 тим, за останніми даними Державної казначейської служби станом на 1 листопада 2020 року залишок коштів на Єдиному казначейському рахунку становить 15146 млн грн., що на $28,8 \%$ або на 613 млн грн менше показника на 1 жовтня (21275 млн грн). Станом на 1 листопада 2019 року залишок коштів на ЄКР становив 53086 млн грн, що в 3,5 рази більше, ніж станом на сьогодні. У вересні-жовтні 2019 року на ЄКР було майже 62 млрд грн.

Таблиця 1

Динаміка зміни залишків на єдиному казначейському рахунку

\begin{tabular}{|c|c|c|c|}
\hline Рік & $\begin{array}{c}\text { Залишки, } \\
\text { млн грн }\end{array}$ & $\begin{array}{c}\text { Відхилення, } \\
\text { млн грн }\end{array}$ & $\begin{array}{c}\text { Темп } \\
\text { приросту, } \\
\mathbf{\%}\end{array}$ \\
\hline на 1.01.2020 & 17547,5 & 7686,5 & 178,0 \\
\hline на 1.01.2019 & 9861,0 & 4762,0 & 93,4 \\
\hline на 1.01.2018 & 5099,0 & $-9158,8$ & $-64,2$ \\
\hline на 1.01.2017 & 14257,8 & 5240,5 & 58,1 \\
\hline на 1.01.2016 & 9017,3 & 6009,8 & 200,0 \\
\hline на 1.01.2015 & 3007,5 & 1268,5 & 73,0 \\
\hline на 1.01.2014 & 1739,0 & 1280,9 & 279,6 \\
\hline на 1.01.2013 & 458,1 & $-1603,6$ & $-77,8$ \\
\hline на 1.01.2012 & 2061,7 & $-662,7$ & $-24,3$ \\
\hline на 1.01.2011 & 2724,4 & 1669,1 & 158,1 \\
\hline на 1.01.2010 1.01 .2009 & 1055,3 & $-6659,4$ & $-86,3$ \\
\hline
\end{tabular}

Джерело: розроблено авторами за даними [3-5]

Ми підтримуемо думку авторів, що «завдяки коштам единого казначейського рахунку здійснюеться покриття тимчасових касових розривів місцевих бюджетів, пов'язаних з недостатньою платоспроможністю місцевого бюджету на конкретну дату погасити бюджетні фінансові зобов'язання за визначеним статтями видатків за рахунок наявних та очікуваних грошових активів загального фонду місцевого бюджету та коштів резервного фонду» [2, с. 128$]$.

Запровадження единого казначейського рахунку, на який зараховуються усі доходи, і з якого здійснюються всі наступні видатки бюджетів, дає змогу зосередити фінансові ресурси на кореспондентському рахунку Державної казначейської служби України.

Отже, «основним завданням Державного казначейства є оперативне управління фінансовими ресурсами в системі казначейства з метою підвищення ефективності використання. Від організації роботи Державного казначейства, насамперед такої його функції, як управління фінансовими ресурсами в системі казначейства, 
Вихідні дані для побудови статистично-математичної моделі

\begin{tabular}{|c|c|c|c|c|}
\hline Роки & Доходи, млн грн & Видатки, млн грн & $\begin{array}{c}\text { Середні значення } \\
\text { залишків на ЄКР, } \\
\text { млн грн }\end{array}$ & $\begin{array}{c}\text { Державний } \\
\text { та гарантований } \\
\text { борг, млн грн }\end{array}$ \\
\hline 2003 & 75286 & 75793 & 1540,4 & 77421,6 \\
\hline 2004 & 91529 & 101416 & 8074 & 85312,3 \\
\hline 2005 & 134183 & 141699 & 8744 & 78126,4 \\
\hline 2006 & 171812 & 175284 & 15912 & 80536,6 \\
\hline 2007 & 219939 & 226036 & 14016 & 88696,8 \\
\hline 2008 & 297845 & 309216 & 13882 & 303093,8 \\
\hline 2009 & 272967 & 307399 & 4906 & 432321,5 \\
\hline 2010 & 257051 & 303589 & 6394 & 473121,6 \\
\hline 2011 & 314617 & 333459 & 7848,5 & 502433,8 \\
\hline 2012 & 345450 & 365138 & 4921 & 584114 \\
\hline 2013 & 442789 & 505844 & 1739 & 1100833 \\
\hline 2014 & 456067 & 523126 & 3007,5 & 1572180 \\
\hline 2015 & 652031 & 679871 & 9017,3 & 1929759 \\
\hline 2016 & 782859 & 835832 & 14257,8 & 2141674 \\
\hline 2017 & 1016970 & 1056973 & 5099 & 2168627 \\
\hline 2018 & 1184291 & 1250189 & 9861 & 2045442 \\
\hline 2019 & 1289849 & 1372350 & 17547,5 & \\
\hline
\end{tabular}

Джерело: розроблено авторами за даними [3-5]

залежатимуть і виконання бюджету, і макроекономічні процеси в державі. Роль казначейської служби в бюджетному процесі та у виконанні бюджету сьогодні вища порівняно з початком його діяльності» [1, с. 95].

На основі звітних даних Державної казначейської служби України за період 2003-2019 років, представлених у табл. 2, нами здійснено спробу визначити залежність обсягу залишків на СКР від основних чинників впливу, таких як: доходи державного бюджету, видатки державного бюджету, стан державного та гарантованого боргу.

На рис. 1 побудовано тренд, що описуе залежність обсягу залишків на СКР від основних чинників впливу на ці обсяги. Графрік тренду У показує, що дослідження залишків коштів на
ЄКР доречно здійснювати за трьома незалежними періодами - 2008-2012 рр., 2012-2017 pp., 2017-2019 рр.

За допомогою MS EXCEL побудовано статистично-математичну модель впливу на середній залишок на СКР (у) доходів державного бюджету $\left(\mathrm{x}^{1}\right)$, видатків державного бюджету $\left(\mathrm{x}^{2}\right)$ та стану державного та гарантованого боргу $\left(\mathrm{x}^{3}\right)$, проте постає потреба в аналізі змінних, що входять до моделі, оскільки. значення F-критерію досить низьке для прогнозування. 3 економічної точки зору зрозуміло, що доходи державного бюджету та видатки державного бюджету є залежними та скорельованими змінними $\left(r_{x 1, x 2}=0,999\right):$ видатки безпосередньо залежать від доходів. Значення множинного коефіціенту

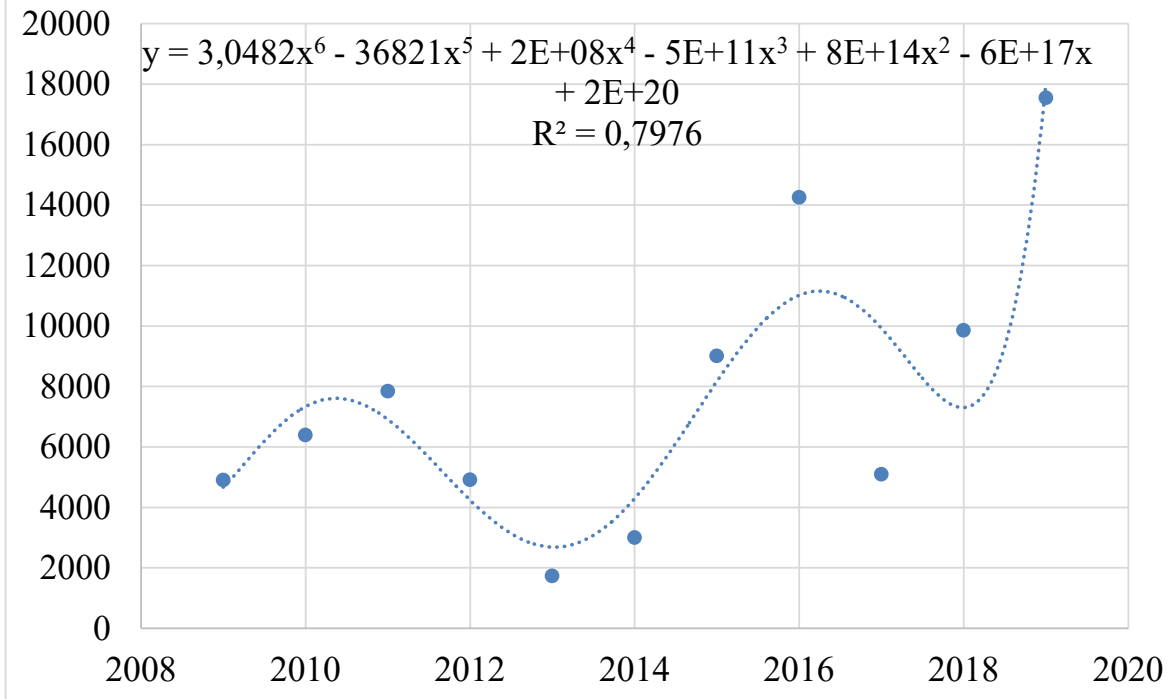

Рис. 1. Поліноміальна лінія тренду залишків СКР 
корелящіі - 0,558 показує, що побудована модель: У3=b0+b1*x1+b2*x2+b3*x3 має рішення, але значущих коефіціентів не має, тобто впливовими є невраховані фрактори.

Висновки і пропозиції. Державна казначейська служба України займає визначальне місце в процесі едрективного управління державним і місцевими бюджетами. Система казначейського виконання бюджетів усіх рівнів бюджетної системи має певні недоліки, про що свідчить аналіз виконання зведеного бюджету України за доходами та видатками. Недовиконання планових показників та низькі темпи зростання до- ходів гальмують виконання видаткової частини бюджетів, що негативно впливає на сощіальноекономічний розвиток. ЄКР в системі виконання бюджетів є запобіжним заходом нецільового використання бюджетних коштів. Динаміка залишку бюджетних коштів на єдиному казначейському рахунку має постійні коливання, що свідчить про перманентні проблеми у розпорядженні бюджетними коштами країни. Невирішеними залишаеться низка проблем, пов'язаних 3 відсутністю ефективних механізмів управління бюджетними коштами в умовах обмеженості фpiнансових ресурсів.

\section{Список літератури:}

1. Курганська Е.І. Система казначейства: управління фрінансовими ресурсами : монографрія. Одеса : ОНЕУ, 2015. 323 c

2. Баранова В.Г., Курганська Е.I. Аналіз дослідження залишків на единому казначейському рахунку. $B i$ сник Міжнародного слов'янського університету. Серія Економічні науки. 2012. Т. 15. № 2. С. $125-131$. URL: http://nbuv.gov.ua/UJRN/VMSU_econ_2012_15_2_21 (дата звернення: 15.12.2020).

3. Офіційний веб-сайт Державної казначейської служби України. Звіт про виконання Зведеного та державного бюджетів України. 2017. URL: https://www.treasury.gov.ua/ua/file-storage/richniy-zvit-pro-vikonannyaderzhavnogo-byudzhetu-ukraini-za-2017-rik (дата звернення: 15.12.2020).

4. Офіційний веб-сайт Державної казначейської служби України. Звіт про виконання Зведеного та державного бюджетів України. 2018. URL: https://www.treasury.gov.ua/ua/file-storage/richnij-zvit-pro-vikonannyaderzhavnogo-byudzhetu-ukrayini-za-2018-rik (дата звернення: 15.12.2020).

5. Офіційний веб-сайт Державної казначейської служби України. Звіт про виконання Зведеного та державного бюджетів України. 2019. URL: https://www.treasury.gov.ua/ua/file-storage/richnij-zvit-pro-vikonannyaderzhavnogo-byudzhetu-ukrayini-za-2019-rik (дата звернення: 15.12.2020).

\section{References:}

1. Kublikova T.B. (2015) Sistema kaznacheystva: upravlinnya finansovimi resursami: monografiya [System Treasury: management of financial resourses: monograph]. Odesa: ONEU, Vid. Atlant. (in Ukrainian)

2. Baranova, V.G., \& Kurganska, E.I. (2012) Analiz doslidzhennya zalyshkiv na yedynomu kaznachejskomu raxunku [Analysis of the study of balances on the single treasury account]. Visnyk Mizhnarodnogo slov'yanskogo universytetu. Ser.: Ekonomichni nauky, t. 15, no. 2, pp. 125-131. Retrieved from: http://nbuv.gov.ua/UJRN/ VMSU_econ_2012_15_2_21 (in Ukrainian)

3. Oficijnyj veb-sajt Derzhavnoyi kaznachejskoyi sluzhby Ukrayiny. Zvit pro vykonannya Zvedenogo ta derzhavnogo byudzhetiv Ukrayiny za 2017 rik [Official website of the State Treasury Service of Ukraine. Report on the implementation of the Consolidated and State Budgets of Ukraine for 2017] treasury.gov.ua. Retrieved from: https://www.treasury.gov.ua/ua/file-storage/richniy-zvit-pro-vikonannya-derzhavnogo-byudzhetu-ukraini-za2017-rik (in Ukrainian)

4. Oficijnyj veb-sajt Derzhavnoyi kaznachejskoyi sluzhby Ukrayiny. Zvit pro vykonannya Zvedenogo ta derzhavnogo byudzhetiv Ukrayiny za 2018 rik [Official website of the State Treasury Service of Ukraine. Report on the implementation of the Consolidated and State Budgets of Ukraine for 2018] treasury.gov.ua. Retrieved from: https://www.treasury.gov.ua/ua/file-storage/richnij-zvit-pro-vikonannya-derzhavnogo-byudzhetu-ukrayini-za2018-rik (in Ukrainian)

5. Oficijnyj veb-sajt Derzhavnoyi kaznachejskoyi sluzhby Ukrayiny. Zvit pro vykonannya Zvedenogo ta derzhavnogo byudzhetiv Ukrayiny za 2019 rik [Official website of the State Treasury Service of Ukraine. Report on the implementation of the Consolidated and State Budgets of Ukraine for 2019] treasury.gov.ua. Retrieved from: https://www.treasury.gov.ua/ua/file-storage/richnij-zvit-pro-vikonannya-derzhavnogo-byudzhetu-ukrayini-za2019-rik (in Ukrainian) 